\title{
Morphology of larval and first juvenile stages of the kangaroo shrimp Dugastella valentina (Crustacea, Decapoda, Caridea), a freshwater atyid with abbreviated development and parental care.
}

\author{
ANTONIO RODRÍGUEZ \& JOSÉ A. CUESTA \\ Instituto de Ciencias Marinas de Andalucía, CSIC, Avenida República Saharaui, 2, E- \\ 11519 Puerto Real, Cádiz, Spain. E-mail: antonio.rodriguez@icman.csic.es, \\ jose.cuesta@icman.csic.es
}

\begin{abstract}
The larval development of Dugastella valentina consists of two zoeal stages and a decapodid. Larval stages are not free living; the complete larval development takes place in the female's incubation chamber. The two zoeae, the decapodid and first postlarval stages still have a large amount of yolk, which ensures their nutritional independence (lecithotrophic stages) while staying within the maternal incubation chamber and the first days after release. The first juvenile is the first free living stage. In the present study the morphology of all larval stages as well as the first juvenile are described and illustrated, and comparison with known larval stages of atyids is made.
\end{abstract}

Key words: lecithotrophic, heterochrony, benthotrophic.

\section{INTRODUCTION}

The kangaroo shrimp Dugastella valentina (Ferrer Galdiano, 1924) is a freshwater atyid shrimp endemic to the Gulf of Valencia area (Spain) in the eastern Iberian Peninsula. The information on the life cycle of $D$. valentina is incomplete, and is almost entirely restricted to data on geographical distribution (Sanz \& Gómez 1984) and preliminary life history results (Sanz Santos \& Sanz 1994). Recently, Cuesta et al. (2006) provided the first data on the larval stages (two zoeae and a decapodid) and the unusual parental care behaviour of this species, in which complete larval development takes place in the female's incubation chamber. However, there are currently no data on the morphology of the larval and postlarval stages.

In the two zoeae and the decapodid stage there is still a large amount of yolk, which ensures the nutritional independence of the larvae (lecithotrophic stages) while they are inside the maternal incubation chamber. The first juvenile is the first free living stage. In the present study the morphology of all the larval stages as well as the first juvenile stage are described and illustrated. We compare these larval stages with the known larval stages of other atyids.

\section{MATERIAL AND METHODS}

More than 100 ovigerous females of Dugastella valentina were collected at different locations in Valencia and Alicante (Spain) over 4 sampling periods during the spring of the years 2005 to 2008 . They were transported live to the laboratory and kept in aquaria in order to study their larval phase and behaviour. 
Taking into account that larval development takes place in the female's incubation chamber, we used two methods to study the morphology of the larval stages: we removed the different larval stages directly from the maternal incubation chamber, and we took terminal eggs and cultured them "in vitro" until they hatched.

Cultured larvae were not fed as Dugastella valentina larvae are obligate lecithotrophs (Anger and Cuesta, unpublished data). The water was changed daily and the larvae were checked for moulting and mortality. Females carried between 25 and 42 eggs each. All the eggs from each female were cultured together, taking into account that larvae do not eat and therefore cannibalism is not expected. More than 50 specimens (cultured and taken from females) of each larval stage and the first juvenile stage were fixed in $70 \%$ ethanol for morphological studies. Exuviae of all the stages were also preserved and examined.

The specimens were dissected under a Wild MZ6 stereo microscope and drawn and measured using a Zeiss Axioskop compound microscope equipped with a camera lucida. Semi-permanent mounts were made of whole larvae. All measurements were taken with an ocular micrometer. Drawings and size measurements were based on 20 larvae from each stage and 10 first juveniles. Total length (tl) was measured from the tip of the rostral spine to the tip of the telson, cephalothorax length (cl) from the base of the rostrum to the posterior margin, and cephalothorax width (cw) as the greatest distance across the cephalothorax.

The descriptions and figures are arranged according to the standards proposed by Clark et al. (1998). Samples of Dugastella valentina larvae (zoea I, zoea II and decapodid) and first juveniles were deposited at the Museo Nacional de Ciencias Naturales (CSIC), Madrid, under catalogue numbers MNCN 20.04/1247, 1248, 1250 and 1251 , respectively.

\section{RESULTS}

The larval development consisted of 2 zoeae and 1 decapodid stage, and lasted 5-9 days from hatching to the first juvenile at $24 \pm 1{ }^{\circ} \mathrm{C}$. The first zoeal stage is described completely, for the subsequent stages only the main differences from the first zoea are described.

\section{Zoea I}

\section{Description \\ Dugastella valentina}

Duration of stage: $1-2$ days

Size: $\mathrm{tl}=2.45 \pm 0.05 \mathrm{~mm} ; \mathrm{cl}=0.80 \pm 0.02 \mathrm{~mm} ; \mathrm{cw}=0.69 \pm 0.05 \mathrm{~mm}$.

Carapace (Figs. 1A, D). Rostrum triangular, very short, acute straight and directed somewhat downwards. Eyes large and sessile.

Antennule (Fig. 2A). Peduncle 3-segmented with a long plumose seta on distal segment. Endopod absent. Exopod unsegmented, broad, with 3 terminal aesthetacs and 2 setae.

Antenna (Fig. 2D). Protopod unsegmented. Endopod long 5-segmented and without setae. Exopod with 11 plumose setae on distal margin.

Mandible (Fig. 3A). Molar process with 6-8 marginal teeth, lacinia mobilis as 1 curved spine. Incisor process with 3 small teeth.

Maxillule (Fig. 3D). Coxal endite with 5 spines (processes). Basal endite with 3 subterminal, and 5-6 terminal spines (processes). Endopod with 2 terminal and 1 subterminal setae. 
Maxilla (Fig. 3G). Coxal endite bilobed, proximal lobe with 10-11 setae, distal lobe with 1 terminal and 2 subterminal plumose setae. Basal endite bilobed, both with 1 terminal and 1 subterminal setae. Endopod with 1 terminal and 1 subterminal setae. Exopod (scaphognatite) with 10 plumose setae on anterior and lateral margin and a long distal stout setose process.

First Maxilliped (Fig. 4A). Biramous. Coxa with 3 setae, 2 simple and 1 plumose. Basis with 4-5 small terminal simple setae. Endopod 4-segmented with 0, 1, 0, 5 setae respectively. Setae plumose on distal segment. The exopod is longer than the endopod with 4 long terminal and 2 short subterminal plumose setae.

Second Maxilliped (Fig. 4D). Biramous. Coxa with 2 simple setae. Basis with 2 sparsely setose setae. Endopod 5-segmented longer that the exopod, isquium and merus both with 1 simple seta, carpus without setae, propodus with 2 distal simple setae and dactylus with a long spinulated and serrate seta, and 1 subterminal and 2 terminal setae. Exopod with 4 long terminal and 2 short subterminal plumose setae.

Third Maxilliped (Fig. 4G).Biramous. Coxa with a elongated bud (epipodite). Basis with 1 simple seta. Endopod 5-segmented longer that the exopod, isquium with 1 simple seta, merus and carpus without setae, propodus with 2 distal simple setae and dactylus with a long spinulated and serrate seta, and 1 subterminal and 2 terminal setae. Exopod with 4 long terminal and 2 short subterminal plumose setae.

Pereiopods (Figs. 5A-E). Uniramous, well developed. Cheliped and second pereiopod slightly segmented and pereiopods third to fifth clearly segmented. Elongated buds (epipodite) on coxa. Terminal segment of Cheliped and second pereiopod slightly quelated.

Abdomen (Figs. 1A, D). Six-segmented, distal segment fused with telson.

Pleopods (Fig. 6D). Biramous. On abdominal segments 1 to 5; exopod and endopod as well developed buds.

Telson (Fig.6A). Diverging posteriorly, indented at median line on posterior margin. Bearing 2 pair of simple setae on lateral margin, $7+7$ plumose setae on posterolateral and posterior margin ( 2 innermost pair smaller), and 2 pair of simple setae on postero-dorsal margin.

Duration of stage: $2-3$ days

\section{Zoea II}

Size: $\mathrm{tl}=2.60 \pm 0.04 \mathrm{~mm} ; \mathrm{cl}=0.83 \pm 0.02 \mathrm{~mm} ; \mathrm{cw}=0.72 \pm 0.04 \mathrm{~mm}$.

Carapace (Figs. 1B, E). Eyes stalked.

Antennule (Fig. 2B). Peduncle 3-segmented, proximal segment with a stylocerite bud in the base, 3 small setae on proximal margin, a strong median spine, 8 long plumose setae on distal edge and 1 subterminal plumose seta. Second segment with 7 plumose setae and 1 simple seta on distal edge, and 1 subterminal plumose seta. Terminal segment with 8 plumose setae on distal edge and 1 median simple seta. Endopod 3-segmented with a median seta on terminal segment. Exopod 2segmented, proximal segment with a subterminal simple seta, distal segment bilobed with 3 aesthetacs on proximal lobe and 2 terminal and 1 subterminal setae on distal lobe.

Antenna (Fig. 2E). Peduncle 3-segmented with 2, 1, 2. setae respectively. Flagellum with 14 segments with $0,1,0,3,2,3,0,4,2,4,0,4,3,5$ setae on proximal to distal 
segment. Exopod (Scaphocerite) with 14-16 plumose setae on median and distal margins, 1 small apical spine and 4 small subterminal dorsal simple setae.

Mandible (Fig. 3B). Molar process with 8-10 teeth. Incisor process with 3 partially fused teeth, largest outermost 2 spines in gap between processes.

Maxillule (Fig. 3E). Coxal endite with 5-6 setae on median and distal margin. Basis with two rows of 10-12 small spines/teeth. Endopod with 1 median long simple seta and 2 small terminal spines.

Maxilla (Fig. 3H). Coxal endite bilobed with inner lobe carrying 12-13 simple setae and 6-7 setose setae, outer lobe reduced with a terminal setae. Basal endite bilobed, inner lobe with 6-7 spine/processes, outer lobe with 5-6 spine/processes. Endopod without setae. Scaphognatite with 16-17 plumose setae on distal and lateral margins, and 3 distal setose stout processes.

First Maxilliped (Fig. 4B). Coxal endite with 4 setae. Basial endite with 5 long plumose setae and 3 small simple setae. Endopod now carrying 2, 1, 1, 5 setae respectively.

Second Maxilliped (Fig. 4E). Coxal and basial endites without setae. Endopod now carrying $0,1,0,1,6-7$ simple setae, respectively.

Third Maxilliped (Fig. 4H). Endopod now with merus with a distal simple seta, carpus with 2 distal simple setae, and propodus with 5 median and 2 distal simple setae.

Pereiopods (Figs. 5F-J). Well developed chela in first and second pereiopod, propodus and dactylus distinct, carrying terminal cluster of small spines. Setation of the rest of appendages as figured.

Abdomen (Figs. 1B, E). Without changes respect to zoea I.

Pleopods (Fig. 6E). All fully articulated. Basis with a terminal seta. Endopod with 2 terminal and 2 subterminal simple setae, and distinct appendix interna with 2 terminal cincinuli. Exopod with 7-8 plumose setae on distal and median margins.

Telson (Fig. 6B). Bearing 4 pairs of simple setae on lateral margins, $8+8$ plumose setae on postero-lateral and posterior margins, 5 pairs of dorso-median simple setae, and 3 pairs of posterodorsal simple setae.

Duration of stage: $2-4$ days

\section{Decapodid}

Size: $\mathrm{tl}=3.26 \pm 0.05 \mathrm{~mm} ; \mathrm{cl}=0.97 \pm 0.03 \mathrm{~mm} ; \mathrm{cw}=0.74 \pm 0.04 \mathrm{~mm}$.

Carapace (Figs. 1C, F). With 2 pair of simple setae on dorsal edge of rostrum.

Antennule (Fig. 2C). Stylocerite with angular projection, and 5 plumose setae on proximal margin, 7 long plumose setae on distal edge and 2 subterminal plumose setae. Second segment with 7 plumose setae on distal edge and 2 subterminal plumose setae. Endopod 4-segmented, with 0, 2, 0, 4 setae on proximal to distal segment. Exopod 3-segmented with 0, 1, and 3 aesthetacs +2 terminal and 2 subterminal setae.

Antenna (Fig. 2F). Peduncle 3-segmented with 1, 3, 4 setae respectively. Flagellum with 17 segments with $0,1,2,0,3,2,0,2,3,2,4,2,5,2,4,3,5$ setae respectively. Exopod (Scaphocerite), with 17-19 plumose setae on median and distal margins, and 5 subterminal dorsal simple setae.

Mandible (Fig. 3C). Lacinia mobilis with 5-6 spines in row. Incisor process with 4 teeth.

Maxillule (Fig, 3F). Basial endite with 2 rows of 12-14 small spines/teeth. Endopod with only 1 median long simple seta. 
Maxilla (Fig. 3I). Coxal endite bilobed, the inner lobe with two rows of 9-10 long simple setae and 6-7 sparsely plumose setae on median and distal edge, outer lobe reduced to a small bud without setae. Basial endite bilobed, the inner lobe with 2 rows of 10 small spines/teeth on distal margin, the outer lobe with 14-15 small spines/teeth on distal margin. Scaphognathite with 22-23 plumose setae on distal and lateral margin, 1 distal setose stout process, and 2 subterminal plumose setae.

First Maxilliped (Fig. 4C). Coxal endite with a small bud (epipodite) and without setae. Basial endite with 30-32 minute spines/teeth. Endopod unsegmented with 3 small simple setae. Exopod unsegmented without setae.

Second Maxilliped (Fig. 4F). Coxa with epipod. Endopod now carrying 0, 1, 0, 3, 9-10 setae, from proximal to distal segment.

Third Maxilliped (Fig. 4I). Coxa with epipod elongated. Basis with 4 sparcely plumose setae. Endopod now with 1, 0, 5, 10-11, 5 setae.

Pereiopods (Figs. 5K-O). Cheliped and second pereiopod with well developed brushlike setae on distal part of propodus and dactylus. Setation of all appendages as figured.

Abdomen (Figs. 1C, 1F). Abdomen sixth segment differentiated from telson.

Pleopods (Figs. 6C, F). Endopod with 2 long terminal and 2 subterminal plumose setae. Exopod with 9 plumose setae on median and distal margin and 2 simple setae on dorso distal margin. Uropods biramous, the endopod reduced with 3-4 plumose setae, the exopod with 10 plumose setae on distal and lateral margin.

Telson (Fig. 6C). Bearing 3 pairs of simple setae on lateral margins, and 4 pairs of dorso-median simple setae.

First Juvenile

Size: $\mathrm{tl}=3.89 \pm 0.04 \mathrm{~mm} ; \mathrm{cl}=1.13 \pm 0.03 \mathrm{~mm} ; \mathrm{cw}=0.81 \pm 0.02 \mathrm{~mm}$.

Carapace (Figs. 7A, B). Rostrum with 4-5 pairs of simple setae on dorsal edge. Small antennal and pterygostomian spines.

Antennule (Fig. 7D). Stylocerite with 2 plumose setae on distal angular projection. Proximal segment of peduncle with 4 median plumose setae and 8 plumose setae on distal edge. Third segment with 2 median and 6 plumose setae on distal edge. Endopod now with 0, 2, 3, 4 setae on proximal to distal segment. Exopod 4segmented, the proximal segment without setae, the second one with 2 setae on distal edge, the third segment bilobed with 2 aesthetacs on the proximal lobe, and 1 subterminal and 2 terminal setae on distal segment.

Antenna (Fig. 7C). Coxa with small projection. Basis with a small spine on distal margin. Endopod peduncle with 0. 4, 5 setae on proximal to distal segment, flagellum with 23 segments with $0,2,0,2,3,0,2,0,3,0,2,2,2,3,5,3,5,5,0$, 3, 4, 4, 5 setae respectively. Exopod (scaphocerite) with 20-23 plumose setae on median and distal margins, and 2 small dorso-median simple setae.

Mandible (Fig. 7E). Molar process with 12-14 teeth, and 4-5 spines. Lacinia mobilis with 6-7 spines in row. Incisor process with 3 partially fused teeth, and 2 serrated setae in gap between processes.

Maxillule (Fig. 7F). Coxal endite with 15-16 setae on distal margin, 4 small spines on subterminal margin and 6 long simple setae on median dorsal margin. Basial endite with 2 small setae on proximal margin and 19-20 terminal spines/teeth. Endopod with 2 subterminal setae and one terminal small spine.

Maxilla (Fig.7G). Coxal endite not bilobed carrying 30-35 setae on distal and lateral margin, and 6-7 long simple setae on median dorsal margin. Basial endite bilobed, 
the inner with 18-20 setae on distal margin, and 16 setae on submargin, the outer with 9-10 setae on distal and lateral margin and 4-5 setae on distal submargin. Scaphognathite with 29-31 plumose marginal setae.

First Maxilliped (Fig.8A). Coxal endite with 8 plumose setae. Basial endite with aproximately 45 setae as show the figure. Exopod with 5 plumose setae on lateral margin.

Second Maxilliped (Fig. 8B). Coxal endite with epipodite elongated , 1 plumose setae and 2 long setae with setules distally. Basial endite with 4 plumose setae. Endopod proximal segment with $6+1$ sparsely setose setae, second one with 1 median and 2 distal setae, third segment with 1distal seta, fourth segment with 6 plumose setae, and distal segment with 18+4 setae sparcely setose.

Third Maxilliped (Fig. 8C). Coxal endite with elongated epipodite, 6 setae and a long setae with setules distally. Basial endite with 6 setae. Endopod now with 3, 8, 7, 18, 8 setae and spines respectively.

Pereiopods (Figs. 8D-F). Coxa with elongated epipodite and 1 long setae setose distally in all pereiopods. Cheliped and second pereiopod chela well developed with propodus and dactylus with brushlike setae on distal angle and setose as show in Fig. E. Second to fifth pereiopods setation and spinulation as show in Fig. 8F. Abdomen (Figs.7A, B). Somites 1-5 with setae on lateral and ventral margins. Somite 6 with setae on dorsal, lateral and ventral margins.

Pleopods (Figs. 8F, H). Pleopods 1 to 5 and uropods well developed, setation as figured. Telson (Fig. 8I). Telson rectangular, setation as figured.

\section{DISCUSSION}

The number of larval stages in atyids varies greatly (see Hayashi \& Hamano 1984; Walsh 1993), and ranges from direct development to 6-9 zoeal stages; this characteristic is important to take into account when morphological features of what are theoretically the same larval stage are compared. This wide range of development types (direct (DD), abbreviated (AD) and extended (ED)) does not always correspond clearly with species habitat as would be expected, and there are cases of extended development in freshwater species, such as Atyaephyra desmarestii (Millet, 1832) (see Gauthier 1924), as well as abbreviated development in saline-water species (Halocaridina rubra Holthuis, 1963, see Couret and Wong 1978). In the case of extended development in freshwater habitats, the larvae are benthonic instead of planktonic. An explanation for this is that there has been no evolutionary pressure to shorten the number of larval stages since larvae feed on benthic substrata (benthotrophic). However, that it is an adaptation to reduce downstream displacement, or the effects of salinity and temperature has also been considered (see Hancock, 1998).

In the case of the freshwater shrimp Dugastella valentina, several morphological characters show that the larvae have abbreviated development: a large amount of yolk in the first stages, and a generally low number of setae, especially in the mouthparts, due to the absence of feeding behaviour, which is expected in this type of development. Despite being larvae with abbreviated development and the peculiar parental care behaviour of this species (only found in the remaining species of this genus, Dugastella marocana Bouvier, 1912 (Hughet et al. 2011)), the general morphology of the larval stages is not affected and their morphological characters can be compared with those of other atyids.

Atyidae is one of the Caridean families with the most species (approximately 450 in 42 genera), and is only exceeded by Palaemonidae and Alpheidae (940 and 630 
species respectively) (see De Grave 2009). However, the larval stages are only known for 27 species and subspecies belonging to 7 genera, and therefore it is currently not possible to come to conclusions on typical features for this family. Table 1 shows a comparison of a selected group of atyid species with known larval stages, and considers the three main development types. It is possible to compare the larval morphology of the species with the same development type, but comparing species with different development types is more difficult considering the differences in the number of zoeae and variability in appendage setation. In several previous studies, the larval stages have been inaccurately named as zoeal stages, megalopa or simply "stages", in the present study we have differentiated two larval forms, "zoea" and "decapodid", and a postlarval stage (juvenile) according to the definitions in Anger (2001). We have applied this nomenclature to the references listed in Table 1.

We compared the morphological characters of the zoea I of atyids with different development types (see Table 1) and found the following main differences: a) the presence of an exopod with 2-4 long plumose setae on the maxillule of species with ED (this character is present in some cases until zoea II or III) that is absent in species with $\mathrm{AD}$ and $\mathrm{DD}$; b) 5 plumose setae on the scaphognatite of maxilla of species with ED, 710 setae on species with $\mathrm{AD}$, and 14-50 setae in those with DD; and c) 7+7 setae on the telson (with a pronounced notch) in species with $\mathrm{ED}, 7+7$ setae on the telson (but without a pronounced notch) in species with $\mathrm{AD}$, and $8+8$ setae (or more in some cases) on a rounded telson in species with DD. These and other features that appear at different stages in the zoeal and decapodid sequences are examples of heterochrony. Similar cases have been previously described in other decapods (see Clark 2005a, b).

A remarkable feature in the larval development of $D$. valentina is the absence of the inner lobe of the maxillar coxal endite in the first juvenile stage (Fig. 7G), which is well developed in zoea I, a small lobe in zoea II, and vestigial in the decapodid stage (see Figs. 3G-H). Benzie (1982) suggested that the gradual loss of this lobe over the development stages could be a typical feature of the Atyidae; however, there is one exception, in Paratya australiensis it is still present at the juvenile stage (see Walsh, 1993) and therefore it is still early to conclude that it is characteristic of atyid larval development.

Due to the parental care these larval stages behave differently to free living larvae. The two zoeal stages do not swim; they do not really move at all and remain immobile at the bottom of the culture bowls until they moult. The decapodid is the first stage that moves; however, the larvae walk using the pereiopods instead of swimming with pleopods, and are still not very active. This inhibition of the swimming activity is a good adaptation to living in a limited space, such as the female's abdominal enclosure However, in other species with this type of parental care, such as Tunicotheres moseri, this is a facultative behaviour and swimming was observed in larvae cultured in vitro (see Bolaños et al. 2004).

Larval stages do not feed as they are obligate lecithotrophs (Anger \& Cuesta, in prep.), which is also a good adaptation for avoiding cannibalism in confined larvae. The first juvenile (first free living stage) as well as the second and even third juvenile stages still have some yolk as they are facultative lecitotrophs (Anger \& Cuesta, in prep.). In Atyidae a similar case has only been described in Caridina mccullochi Roux, 1926 (see Benzie 1982), a freshwater shrimp whose two zoeal stages are also obligate lecithotrophs, the rest of the larvae of atyid species with ED and DD are benthotrophic. 


\section{ACKNOWLEGMENTS}

We thank Sebastian Sanz Santos for kindly help in locating several populations of $D$. valentina in the Gulf of Valencia. Research was funded by the Spanish "Ministerio de Educación y Ciencia, Plan Nacional I+D" and EU funds FEDER to project CGL200401083.

\section{REFERENCES}

Anger, K. (2001) The biology of decapod crustacean larvae. Crustacean Issues, vol. 14. A.A. Balkema Publishers. The Netherlands, 419 pp.

Benzie, J.A.H. (1982) The complete larval development of Caridina mccullochi Roux, 1926 (Decapoda, Atyidae) reared in the laboratory. Journal of Crustacean Biology, 2, 493-513.

Benzie, J.A.H. \& de Silva, P.K. (1983) The abbreviated larval development of Caridina singhalensis Ortmann, 1894 (Decapoda, Atyidae). Journal of Crustacean Biology, 3, 117-126.

Bolaños, J., Cuesta, J.A., Hernández, G., Hernández, J. \& Felder, D.L. (2004) Abbreviated larval development of Tunicotheres moseri (Rathbun, 1918) (Decapoda: Pinnotheridae), a rare case of parental care among brachyuran crabs. Scientia Marina, 68, 373-383.

Clark, P.F., Calazans, D.K. \& Pohle, G.W. (1998) Accuracy and standardization of brachyuran larval descriptions. Invertebrate Reproduction \& Development, 33, 127-144.

Clark, P.F. (2005a) The evolutionary significance of heterochrony in the abbreviated zoeal development of pilumnine crabs (Crustacea: Brachyura: Xanthoidea). Zoological Journal of the Linnean Society, 143, 417-446.

Clark, P.F. (2005b) The first-stage zoeas of Carpilius convexus (Forskal, 1775) and Carpilius maculatus (Linnaeus, 1758) (Crustacea: Decapoda: Brachyura: Xanthoidea: Carpiliidae): na example of heterochrony. Journal of Plankton Research, 27, 211-219.

Cuesta, J.A., Palacios-Theil, E., Drake, P. \& Rodríguez, A. (2006) A new rare case of parental care in decapods. Crustaceana, 79, 1401-1405.

Couret, C.L. Jr. \& Wong, D.C.L. (1978) Larval development of Halocaridina rubra Holthuis (Decapoda, Atyidae). Crustaceana, 34, 301-309.

De Grave, S., Pentcheff, N.D., Ahyong, S.T., Chan, T.-Y., Crandall, K.A., Dworschak, P.C., Felder, D.L., Feldmann, R.M., Fransen, C.H.J.M., Goulding, L.Y.D., Lemaitre, R., Low, M.E.Y., Martin, J.W., Ng, P.K.L., Schweitzer, C.E., Tan, S.H., Tshudy, D. \& Wetzer, R. (2009) A classification of living and fossil genera of decapod crustaceans. The Raffles Bulletin of Zoology, Suppl. 21, 1-109.

Gauthier, H. (1924) Recherches sur le dévelopement larvaire d'Atyaephyra desmarestii (Millet, 1832) (Dècapodes, Natantia, Caridea, Atyidés). Bulletin de la Société d'histoire naturelle d'Afrique du Nord, 15, 337-376.

Glaister, J.P. (1976) Postembryonic growth and development of Caridina nilótica aurensis Roux (Decapoda: Atyidae) reared in the laboratory. Australian Journal of Marine and Freshwater Research, 27, 263-276.

Hayashi, K.I. \& Hamano, T. (1984) The complete larval development of Caridina japonica De Man (Decapoda, Caridea, Atyidae) reared in the laboratory. Zoological Science, 1, 571-589. 
Hancock, M.A. (1998) The relationship between egg size and embryonic and larval development in the freshwater shrimp Paratya australiensis Kemp (Decapoda: Atyidae). Freshwater Biology, 39, 715-723.

Huguet, D., García Muñoz, J.E., García Raso, J.E. \& Cuesta, J.A. (2011) Extended parental care in the freshwater shrimp genus Dugastella Bouvier (Decapoda, Atyidae, Paratyinae). Crustaceana, 84, 251-255.

Hunte, W. (1979a) The complete larval development of the freshwater shrimp Atya innocous (Herbst) reared in the laboratory (Decapoda, Atyidae). Crustaceana, Supplement 5, 231-242.

Hunte, W. (1979b) The complete larval development of the freshwater shrimp Micratya poeyi (Guérin-Méneville) reared in the laboratory (Decapoda, Atyidae). Crustaceana, Supplement 5, 153-166.

Hussein, M.A. \& Obuid-Allah, A.H. (1989) Larval development of the freshwater prawn Caridina nilotica nilotica in Egypt. Zoology in the Middle East, 3, 113128.

Lai, H.T. \& Shy, J.Y. (2009) The larval development of Caridina pseudodenticulata (Crustacea: Decapoda: Atyidae) reared in the laboratory, with a discussion of larval metamorphosis types. The Raffles Bulletin of Zoology, Supplement 20, 97107.

Pillai, N.N. (1975) Larval development of Caridina pseudogracilirostris reared in the laboratory. Journal of the Marine Biological Association of India, 17, 1-17.

Ravindranath, K. (1981) Larval stages of a freshwater shrimp, Caridina rajadhari Bouvier (Crustacea, Decapoda, Atyidae). Proceedings of the Indian Academy of Sciences, 90, 683-702.

Salman, S.D. (1987) Larval development of Caridina babaulti basrensis Al-Adhub \& Hamzah (Decapoda, Caridea, Atyidae) reared in the laboratory. Crustaceana, 53, 229-244.

Sanz Brau, A. \& Gomez, P. (1984) Distribución geográfica de Dugastella valentina (Ferrer Galdiano, 1924) (Crustacea: Atyidae). Limnetica, 1, 336-339.

Sanz Santos, S. \& Sanz Brau, A. (1994) Preliminary results on the life history of Dugastella valentina (Ferrer Galdiano, 1924) (Crustacea: Atyidae) in the Mijares River, Valencia (Spain). Verhandlungen des Internationalen Verein Limnologie, $25,2454$.

Shokita, S. (1973) Abbreviated development of freshwater atyid shrimp, Caridina brevirostris Stimpson from Iriomote Island of the Ryukyus (Decapoda, Atyidae). Bulletin of Science and Engineering Division, University of the Ryukyus (Mathematics \& Natural Science), 16, 222-231.

Shy, J.Y., Lai, H.T. \& Yu, H.P. (2001) On the larval development of Caridina formosae (Decapoda, Atyidae) reared in the laboratory. Crustaceana, 74, 1159-1168.

Walsh, C.J. (1993) Larval development of Paratya australiensis Kemp, 1917 (Decapoda: Caridea: Atyidae), reared in the laboratory, with comparisons of fecundity and egg and larval size between estuarine and riverine environments. Journal of Crustacean Biology, 13, 456-480. 


\section{FIGURE CAPTIONS}

FIGURE 1. Dugastella valentina (Ferrer Galdiano, 1924), lateral view: A, zoea I; B, zoea II; C, decapodid; dorsal view: D, zoea I; E, zoea II; F, decapodid. Scale bar = $1 \mathrm{~mm}$.

FIGURE 2. Dugastella valentina (Ferrer Galdiano, 1924), antennule: A, zoea I; B, zoea II; C, decapodid; antenna: D, zoea I; E, zoea II; F, decapodid. Scale bar $=0.25$ $\mathrm{mm}$.

FIGURE 3. Dugastella valentina (Ferrer Galdiano, 1924), mandible: A, zoea I; B, zoea II; C, decapodid; maxillule: D, zoea I; E, zoea II; F, decapodid; maxilla: G,zoea I; $\mathrm{H}$, zoea II; I, decapodid. Scale bars $=0.1 \mathrm{~mm}$.

FIGURE 4. Dugastella valentina (Ferrer Galdiano, 1924), first maxilliped: A, zoea I; B, zoea II; C, decapodid; second maxilliped: D, zoea I; E, zoea II; F, decapodid; third maxilliped: G,zoea I; H, zoea II; I, decapodid. Scale bar $=0.25 \mathrm{~mm}$.

FIGURE 5. Dugastella valentina (Ferrer Galdiano, 1924), pereiopods: A-E, zoea I; F-J, zoea II; K-O, decapodid. Scale bar $=0.25 \mathrm{~mm}$.

FIGURE 6. Dugastella valentina (Ferrer Galdiano, 1924), telson: A, zoea I; B, zoea II; C, decapodid; third pleopod: D, zoea I; E, zoea II; F, decapodid. Scale bar $=0.5$ $\mathrm{mm}$ (A-C), $0.25 \mathrm{~mm}$ (D-F).

FIGURE 7. Dugastella valentina (Ferrer Galdiano, 1924), first juvenile: A, lateral view; B, dorsal view; C, antenna; D, antennule; E, mandible; F,maxillule; G, maxilla. Scale bars $=1 \mathrm{~mm}(\mathrm{~A}, \mathrm{~B}), 0.1 \mathrm{~mm}(\mathrm{C}-\mathrm{G})$.

FIGURE 8. Dugastella valentina (Ferrer Galdiano, 1924), first juvenile: A, first maxilliped; B, second maxilliped; $\mathrm{C}$, third maxilliped; D, first pereiopod; E magnification of chela; F, third pereiopod; G, third pleopod; H, uropod; I, telson. Scale bars $=0.1 \mathrm{~mm}$. 

TABLE 1. Morphological and meristic characters of a selection of atyid species with known larval stages. Abbreviations: (-), absent; E, extended; A, abbreviated; D, direct.

\begin{tabular}{|c|c|c|c|c|c|c|}
\hline Species & $\begin{array}{c}\text { No. Zoeal } \\
\text { stages }\end{array}$ & $\begin{array}{c}\text { Type of } \\
\text { development }\end{array}$ & $\begin{array}{c}\text { Presence of } \\
\text { setose exopod } \\
\text { on maxillule } \\
\text { (No. setae) }\end{array}$ & $\begin{array}{c}\text { No. setae on } \\
\text { scaphognatite } \\
\text { of zoea I } \\
\text { maxilla } \\
\end{array}$ & $\begin{array}{c}\text { No. setae on } \\
\text { telson } \\
\text { (hatched } \\
\text { indiv.) } \\
\end{array}$ & Reference \\
\hline Atya innocua & 9 & $\mathrm{E}$ & ZI-III (4) & 5 & $7+7$ & Hunte (1979a) \\
\hline Caridina japonica & 8 & $\mathrm{E}$ & No data & 5 & $7+7$ & Hayashi \& Hamano (1984) \\
\hline Caridina rajadhari & 8 & $\mathrm{E}$ & ZI (2) & 5 & $7+7$ & Ravindranath (1981) \\
\hline Micratya poeyi & 7 & $\mathrm{E}$ & ZI-III (3) & 5 & $7+7$ & Hunte (1979b) \\
\hline Paratya australiensis & 7 & $\mathrm{E}$ & ZI-IV (3) & 5 & $7+7$ & Walsh (1993) \\
\hline Atyaephyra desmarestii & 7 & $\mathrm{E}$ & ZI-IV (3) & 5 & $7+7$ & Gauthier (1924) \\
\hline Caridina pseudogracilirostris & 6 & $\mathrm{E}$ & ZI-II (2) & 5 & $7+7$ & Pillai (1975) \\
\hline Caridina babaulti basrensis & 5 & $\mathrm{E}$ & ZI-II (2) & 5 & $7+7$ & Salman (1987) \\
\hline Caridina nilotica nilotica & 4 & $\mathrm{E}$ & $(-)$ & 5 & $7+7$ & Hussein \& Obuid-Allah (1989) \\
\hline Caridina nilotica aruensis & 4 & $E-A^{(1)}$ & $(-)$ & 5 & $7+7$ & Glaister (1976) \\
\hline Caridina mccullochi & 2 & A & $(-)$ & 7 & $7+7$ & Benzie (1982) \\
\hline Dugastella valentina & 2 & A & $(-)$ & 10 & $7+7$ & Present study \\
\hline Neocaridina brevirostris & 0 & $\mathrm{D}$ & $(-)$ & $36-37$ & $8+8$ & Shokita (1973) \\
\hline Caridina formosae & 0 & $\mathrm{D}$ & $(-)$ & 14 & $8+8$ & Shy et al. (2001) \\
\hline Caridina pseudodenticulata & 0 & $\mathrm{D}$ & $(-)$ & 18 & $8+8$ & Lai \& Shy (2009) \\
\hline Caridina shighalensis & 0 & $\mathrm{D}$ & $(-)$ & 50 & $10-11+10-11$ & Benzie \& Silva (1983) \\
\hline
\end{tabular}

(1) Intermediate development, extended type with some character of abbreviated development. 